\title{
Lexis
}

Journal in English Lexicology

$11 \mid 2018$

Lexis in Languages for Specific Purposes (LSP)

\section{Is legal lexis a characteristic of legal language?}

\section{Isabelle Richard}

\section{OpenEdition}

\section{Journals}

Electronic version

URL: http://journals.openedition.org/lexis/1173

DOI: $10.4000 /$ lexis. 1173

ISSN: 1951-6215

\section{Publisher}

Université Jean Moulin - Lyon 3

\section{Electronic reference}

Isabelle Richard, «Is legal lexis a characteristic of legal language? », Lexis [Online], 11 | 2018, Online since 30 April 2018, connection on 19 April 2019. URL : http://journals.openedition.org/lexis/1173 ; DOI : 10.4000/lexis. 1173

This text was automatically generated on 19 April 2019

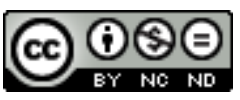

Lexis is licensed under a Creative Commons Attribution-NonCommercial-NoDerivatives 4.0 International License. 


\title{
Is legal lexis a characteristic of legal language?
}

\author{
Isabelle Richard
}

\section{Introduction}

1 It is common knowledge that specialised languages use lexico-grammatical features of natural languages to express the communicative objectives of specialised communities. Compiling and analysing specialised corpora is one way of identifying recurrent features that tend to shed light on these special uses. As a result, it is possible to draw up a list of the linguistic characteristics specific to a specialised language, such as the use of a special lexicon or special grammatical features. These features are "special" only in that they reflect how a specialised language under-uses or overuses certain lexical and grammatical features of a given language (Sourioux \& Lerat [1975: 44], Lerat [1995: 40]). For instance, as shown elsewhere (Richard [2006: 138] \& [2008: 13-14]), the law needs to be generic due to its normative character ${ }^{1}$, one effect of which is that it entails a large number of impersonal utterances in legal language, notably a wide use - and possibly overdeveloped use when compared to general English - of the passive voice. Some of these features are so specific compared to other varieties of languages, whether specialised or not, that they will naturally be identified as typical of, say, legal English, economic English and so on. Therefore, lexis - and, to some extent, grammar - appears to be distinct from one specialised language to another, or from non-specialised languages to specialised languages, which would tend to show that specialised lexicons, together with some grammatical features, are a defining feature of specialised languages.

2 Yet, as we will show, much of legal lexis is shared by other types of language, in particular everyday, non-specialised language, which implies that legal lexis is necessarily polysemous. Therefore the question is: how legal/specialised is legal lexis? Or, put differently: what makes legal lexis legal? Can legal lexis be considered a characteristic of legal language? Such questions require us to define the communicative needs of the legal domain on the one hand, and legal lexis on the other, including those units which are 
borrowed, for the most part, from general English. What part of legal lexis do they represent and to what extent can they be considered as "specialised"?

Before going any further, we need to look at three fundamental elements regarding legal language and legal lexis. The first one has to do with the very definition of legal lexis. A narrow definition includes all the lexical units bearing at least one legal meaning (Cornu [2005: 14]), which means that these elements are likely to feature in legal dictionaries, the aim of which is "to register the language" as Johnson wrote when he published his Dictionary of the English Language in 1755. This narrow definition also implies that some units also have non-legal meaning(s). In a broader definition, on the other hand, legal lexis comprises all the lexical units used by law to achieve its communicative ends, whether these ends regard intra-professional communication between legal experts (lawyers, judges etc.), or inter-professional communication between legal experts and lay people (Isani [2011: \$16]). This broader definition implies that certain legal units do not have any specific legal meaning outside of a legal context, and that others have no legal meaning at all and will require specific legal rules of interpretation to be understood in a particular legal context. As a matter of fact, and this is the second element that must be borne in mind, there are no hermetic lexical - nor any grammatical - borders between legal language and non-legal language. As we will show, the law has borrowed innumerable lexical units from other types of languages and domains, in particular the general and religious ones, and in doing so has attributed to them one or more legal meaning(s). The third element we need to take into account and which ensues from the first two, is that legal lexical units rarely have any exclusively legal meaning. Polysemy, consequently, is unquestionably one of the major characteristics of legal lexis in English. In this context, we need to distinguish between internal polysemy (one unit has several meanings in law) and external polysemy (one unit has at least one legal meaning and one non-legal meaning). Besides, these two types of polysemy may coexist, since a lexeme borrowed from general English may have different legal meanings, as is the case with, for example, the verb "apprehend", or the noun "assessment" which may be interpreted in four different ways depending on the branch of the law it is used in.

In view of these considerations, this article will first focus on some of the borrowings that characterise legal lexis in English and then look at some of the interpretation difficulties posed by a number of lexical units that do not stand out as being "legal" but yet consistently appear in legal messages and are recorded, for some of them, in legal dictionaries.

\section{Legal Lexical Borrowings}

5 A loanword (or lexical borrowing) may be defined as "a word that at some point in the history of a language entered its lexicon as a result of borrowing (or transfer, or copying)" (Haspelmath [2009: 36]). In most definitions, the term "lexical borrowing" describes both the diachronic process through which lexical units are copied into the recipient language and the borrowed units themselves. Unsurprisingly, lexical borrowings are closely linked to the history of English law and legal English, and as such form a major characteristic of legal lexis.

6 Four major types of loanwords may be identified. The first consists in copying words from a foreign language into legal English. The donor/source languages are mainly old Norse (a language spoken by the Vikings who settled in England between the $8^{\text {th }}$ and $13^{\text {th }}$ 
centuries), Latin (especially at the time of the development of Christianity in England since 596, with a loanword peak in the $10^{\text {th }}$ century) and Norman French which has undoubtedly left the largest number of traces in legal English as we know it today. Loanwords often undergo some morphological and/or syntactic changes so that they "will fit better into the recipient language. These changes are generally called loanword adaptation" (Haspelmath [2009: 42]).

7 A second type of borrowing concerns lexical units coming from domains other than the law. Two domains may be mentioned in particular. The first is the religious domain. Some of the most emblematic examples are the lexemes "cell", which originally meant a monk's cell, and "clerk", which originally referred to the Catholic priests who were in charge of drawing up the writs². Besides, some of the most well-known legal conceptual metaphors directly originate from the religious sphere, such as "act of God", "fruit of the poisonous tree", "prayer for relief" or "the neighbour principle", for instance. The second domain is the general or non-specialised English domain. General English loanwords were inevitable since legal English is part and parcel of the English language. These borrowings from general English have undoubtedly enriched legal lexis but they have also given rise to interpretation issues.

8 A third type of borrowing is that of lexical units borrowed by one Common Law system from another. This is due to the fact that English Common Law has spread in the former English colonies all over the world, resulting in some of its lexemes existing in other Common Law languages, but not without potential changes in meaning ${ }^{3}$. Additionally, one may consider a fourth type of borrowing which follows the opposite direction, i.e. lexemes borrowed from legal English by other domains/activities. Though an interesting line of enquiry in itself, for the purposes of this article such borrowings will not be taken into account.

\subsection{Foreign lexical borrowings}

The reasons behind foreign lexical borrowings are diverse and not always easy to pinpoint. Most may be put down to the successive invasions that took place in England between the $5^{\text {th }}$ and the $11^{\text {th }}$ centuries (namely, the Romans, the Anglo-Saxons, the Danes ${ }^{4}$ and the Normans), and to the ways in which Common Law slowly developed in England. Some lexemes were borrowed either because they referred to legal concepts that were unknown in the legal system at the time and considered useful ("murder", "outlaw", "bond" and "trust" all come from old Norse and Dane Law for instance) or because they designated foreign legal concepts that were specifically applied to the foreign populations living in Anglo-Saxon territory (mostly Danes) and which slowly found their way into legal English ${ }^{5}$ (usually by undergoing some degree of morphological adaptation).

The loan process was different in the case of Latin as many Latin words came to be incorporated into legal English mostly because the writs were originally written in Latin by the priests (Branaa et al [2006: 9], Lévy-Ullmann [1999: 145-146]). As a matter of fact, many of the lexemes used in procedural English originate from Latin ("counsel", "counsellor", "attorney", "solicitor", "advocate", "delict", etc.). Some have been translated literally ("in witness whereof", "know all men by these presents", for example), others have kept their initial Latin spelling (subpoena, affidavit, versus, amicus curiae, corpus delicti, per se, habeas corpus, etc. $)^{6}$. 
11 Yet, the language that has had the greatest influence on English legal lexis is undoubtedly French, as Law French was the language of the law in England from the early development of the Common law under the influence of the Normans ${ }^{7}$ until the $18^{\text {th }}$ century when Parliament passed laws (in 1731, 1733 and 1735) to impose English as the only language to be used in legal practice ${ }^{8}$. As a result of use over a protracted period of six or seven centuries, a large number of legal lexical units can be traced back to French origins (Pollock \& Maitland [1968: 80-81]). Over the years, a majority of these have adapted to the English language. An analysis of the $8^{\text {th }}$ edition of Black's Law Dictionary shows that the lexemes that have kept the (old) French spelling only account for $0.20 \%$ of all the entries in this dictionary. Some examples of unaltered old French expressions still present in legal English today are en ventre sa mere, fait accompli, cestui que trust/vie, force majeure, oyez or voir dire.

12 Most of the foreign borrowings discussed above are essentially of a legal nature and would reinforce the hypothesis that legal lexis is indeed "special".

\subsection{Borrowings from non-legal domains}

13 A second category of loanwords which has considerably enriched legal lexis comes from lexemes from non-legal domains. When the law borrows lexical units from other domains, two main semantic phenomena can be distinguished: the loanwords may keep their original meaning(s) - what I refer to as "source-oriented lexis" as it preserves the meaning(s) of the source language - or they are attributed specific legal meaning(s) what I refer to as "recipient-oriented lexis". In both cases, the lexical units in question may not appear to be particularly "legal" per se, and do so only when associated with a lexeme or context which is clearly legal. This is especially obvious when the meaning of the loanwords remains fairly close, if not identical, to the one they had in the donor/ source language ("source-oriented lexis"). One illustration of this phenomenon is the adjective "petty" (or petit) as found in "petty crime", "petty larceny" or "petty jury" under American law: the adjective corresponds exactly to what it means in general French ("small", "minor"), as exemplified by the definition of "petit larceny" provided by the online version of Black's Law Dictionary: "a term for taking another person's property unlawfully where the value of the property is not large". Anyone aware of the original meaning will have no difficulty grasping the meaning of the adjective in any noun phrase.

Similarly, certain lexical units borrowed from the religious domain may also be interpreted according to their initial meaning, such as "act of God" (a natural disaster beyond human control), "redemption" (which refers to some form of release as in "redemption of a debt" or "redemption of mortgage"10), "days of grace" (which was "originally a gratuitous favor, hence its name, but custom has rendered it a legal right", Black's Law Dictionary [1998: 481]), or "pray", which is defined as "to request earnestly" in Garner's Dictionary of Modern Legal Usage [1987: 426] ${ }^{11}$. It follows that the "source-oriented lexis" does not carry any special legal flavour if not used in a legal context or situation. This also holds true in the case of "recipient-oriented lexis", that is to say when the law has attributed specific legal meaning to the loanwords, so that when considered outside of a specific context, these lexemes have both legal and non-legal meanings. 


\subsection{Borrowings from other Common Law systems}

15 A loanword may originally come from another Common Law system and be given a specific meaning in the recipient legal system. As mentioned earlier, colonisation led to the spread of English Common Law all over the world, a phenomenon encapsulated in the tree metaphor, the trunk being the English Common Law system and the branches the other Common Law systems subsequently created through British colonisation. One of the salient consequences of such borrowings concerns the fact that certain legal lexemes do not have the same meaning in American English and in British English: "to table an amendment", for example, means to present it in British English but to postpone it in American English ${ }^{12}$.

\subsection{The importance of context}

16 "Recipient-oriented lexis" thus typically creates false friends (i.e. lexemes sharing a similar morphology but carrying different meanings). "Recipient-oriented lexis" may combine with foreign borrowing processes also. For instance, many lexemes coming from non-legal French have been attributed a legal meaning which may be traceable to the original non-legal word, and sometimes to the original meaning while remaining different from it (such as evidence/"obviousness" and "evidence/proof", and tort and "tort" $\left.{ }^{13}\right)$. In other instances, the law has kept the original meaning(s) and added some specifically legal meaning(s) as is the case with the verb "avoid" (from the old French esvuider through the Latin viduare i.e. "empty") which has the same meaning as in general English ("escape", "evade") but may also mean "cancel", "make void" in contract law. The "recipient-oriented lexis" indicates therefore that the semantic links with the original language or domain have been severed or are too loose to be identified with the original meaning(s).

Whether loanwords belong to the "source-oriented lexis" or the "recipient-oriented lexis", their legal flavour is therefore entirely dependent on context. If one considers any of the examples provided above, none would seem particularly "legal" outside of a legal context ("avoid", "redemption", "grace", "petty", "prayer", for example), except in two opposing cases: the first concerns the lexemes which are also used in everyday English in which case they may have been borrowed by general English from legal English - and which therefore carry a legal flavour whatever the context, as is the case of "evidence" for instance ${ }^{14}$; or, conversely, they are used in legal English exclusively (as is the case of "tort", for example), which does not mean that they will not appear in general English dictionaries. For instance, "tort" is defined as "a wrongful act other than a breach of contract for which relief may be obtained in the form of damages or an injunction" in the US Merriam-Webster Dictionary and as "an action that harms someone and for which you can be judged legally responsible although it is not a crime" 15 in the UK MacMillan Dictionary, both dictionaries being dedicated to providing definitions in ordinary language. In the same way, such non-specialised dictionaries also have an entry for typically legal adverbs such as "herein", "hereinafter", "hereunder", "heretofore" and the like, the majority of which were copied into legal English in the course of the $8^{\text {th }}$ century. As adverbs, they carry no legal meaning but their almost exclusive usage in (usually formal) legal or para-legal contexts automatically gives them a legal flavour. 
Apart from these two specific, opposing uses, borrowed lexemes need to be put into a legal context to acquire their legal meaning(s), which indicates that this part of legal lexis is "legal" only in so far as it is contextualised. Even though an exact assessment of the proportion these lexemes represent in legal lexis would require a thorough analysis of several legal dictionaries, it is reasonably safe to assert that quite a significant part of legal lexis carries non-legal meanings in contexts other than the law - which leads to the conclusion that not only is legal lexis partially polysemous, it is also not specific to the law as a domain. A random look through a legal dictionary highlights the fact that few lexemes actually describe legal concepts and therefore qualify as "terms". In light of this, Wüster's theory [1968] that terms are unequivocal needs to be revisited since terms are not systematically unambiguous and often require some degree of context analysis to be interpreted properly as, for example, the terms belonging to two different Common Law systems. It thus follows that the legal essence of legal lexis is essentially dependent on how legal the message is. We define a legal message as a message creating legal effects, as opposed to non-legal messages - these include "para-legal messages" - which merely talk about the law instead of actually expressing it, such as law-related fiction, newspaper articles and research papers on legal topics, for example ${ }^{16}$.

However, establishing that context is paramount in defining and interpreting legal lexis does not necessarily mean that the meaning becomes clear. As a matter of fact, some specific rules of interpretation are sometimes required to help define how some lexemes should be interpreted in a given legal context. This is particularly true when loanwords are copied into legal English without any change in meaning ("source-oriented legal lexis").

\section{Interpretation issues}

In order to serve its generic purpose, the law commonly borrows some lexemes from general English which, paradoxically enough, cause complex interpretation issues. Two types of lexemes pose special problems due to their generic nature, namely weasel words (words that are intentionally ambiguous and misleading) and hypernyms (words with a broad general meaning that more specific words fall under). The former allows for a degree of imprecision due to their vague character, the latter to create classifications thanks to the semantic hierarchy they imply. In both cases, they echo the normative nature of the law which requires to establish prescriptive rules that will apply to a class of people or to specific functions (hence the impersonality of legal language) and to provide for a variety of situations. These lexemes do not bear any particular legal meaning but are commonly used in legal messages and thus pertain to the broader definition of legal lexis provided in the Introduction.

\subsection{Hypernyms}

21 A hypernym or superordinate may be defined as "a word with a general meaning that includes the meanings of other particular words, for example 'fruit' is the hypernym or superordinate of 'apple', 'orange', etc." [Oxford Leaners Dictionaries, online edition], while "apple", "orange", "pear", etc. are called the "hyponyms" of "fruit". On the face of it, the main advantage of using hypernyms is to avoid drawing up a list of elements concerned by a particular rule for instance, as lists are necessarily incomplete - and are generally 
"hedged" by a word of caution such as "including, without limitation" or "including, but not limited to" in legal texts. As with the example "fruit", many hypernyms are borrowed from everyday English and are not recorded in legal dictionaries (except where they appear in terms such as "fruits of a crime"). It must be noted though that "fruit" features in its Latin form, fructus, in Black's Law Dictionary with a definition that partly matches its plain English definition: "produce; profit or increase; the organic production of a thing" [1998: 462]. The online version of this dictionary offers a definition that is quite close to its plain English definition: "The produce of a tree or plant which contains the seed or is used for food"17.

Resorting to hypernyms offers a threefold advantage: meeting the law's need for genericity; avoiding the risk of omitting an element from a list; and decreasing the complexity of a message by shortening it. Nevertheless, interpretation is not always eased by hypernyms as the semantic relationship between a hypernym and its hyponyms may vary, as pointed out by Rosch's prototype theory [1973]. Pursuant to this psycholinguistic theory, an orange or an apple are more prototypical of "fruit" than a tomato, for instance. This may also be applied to the law, as any hypernym is likely to raise such interpretation issues ${ }^{18}$. A leading case in this context is Nix v. Heddon (1893). Under the 1883 Tariff Act, a 10\% tax was to be imposed on vegetables imported into the United States. Edward L. Hedden, who was then collector of the Port of New York, had imposed duties on tomatoes imported by the plaintiffs in 1886, based on Chapter 121 of the Tariff Act. The plaintiffs claimed that botanically, tomatoes are fruit, not vegetables, and should thus be exempted from the tax. However, US Supreme Court Judge, Mr. Justice Gray, found that as there was no evidence that the words "fruit" and "vegetables" had acquired any special meaning in trade (i.e. the law could not attach any special meaning to either), they must receive their ordinary (prototypical) meaning and accordingly tomatoes must be considered as vegetables. Judgment was therefore held in favour of the defendant. In another case, in Twining $v$. Mayers (1982), the question was to determine whether rollerskates were to be considered as being hyponyms for "vehicle" in the following regulation: "It shall be a criminal offence for any vehicle to enter the park". Interestingly enough, even though the noun "vehicle" does not feature in all legal dictionaries, the adjective "vehicular" does under the entry "vehicular crime" in which it implies the use of a motor vehicle (Blacks' Law Dictionary, [1998: 1078]). The online version of this dictionary offers the following definition for "vehicle", thus broadening its scope: "The word "vehicle" includes every description of carriage or other artificial contrivance used, or capable of being used, as a means of transportation"19. To sum up on this point, as mentioned earlier, hypernyms do not usually feature in legal dictionaries (unless they are part of a term) but are commonly used in legal messages/documents for they help the law meet its need for genericity.

\subsection{Weasel words}

Weasel words are resorted to for similar reasons: they meet the law's need for a certain degree of vagueness and so, unsurprisingly, generate interpretation problems. These lexemes are useful in that they carry the degree of indeterminacy that is sometimes required in law. Another common point they share with hypernyms is that they are copied from general English and do not always feature in legal dictionaries (which tends 
to indicate that their definition is that of plain English), except when they refer to a legal concept. "appropriate". Whenever they are used, detailed contextualisation will be essential to help determine their meaning, especially since their definitions are somewhat fuzzy and vary according to contexts, as demonstrated by the definition of "reasonable" provided by Black's Law Dictionary [1998: 874]: "Fair, proper, just, moderate, suitable under the circumstances". These two adjectives are heavily used in legal documents, notably contracts, which have normative thus prescriptive value ("as may be appropriate", "appropriate use", "appropriate remedy", "as deemed appropriate", "if appropriate", "reasonable time", "reasonable notice", "reasonable doubt", "reasonable force", "reasonable compensation", "reasonable care", etc.). As a matter of fact, the adjective "reasonable" is used in terms that refer to key concepts at Common Law. In the 1998 version of Black's Law Dictionary, it is used in nineteen entries, most of which offer circular definitions as they are based upon the adjective "reasonable" itself or the adverb "reasonably". Initially, the idea of "reasonableness" refers to someone having the faculty of reason. In tort law for instance, the duty of care is measured against that of a "reasonable person" (of the same trade, gender, age, etc. depending on the circumstances of the case) ${ }^{20}$. It follows that what is deemed "reasonable" is relative. This vague notion is therefore crucial in law as it precisely needs to adapt to all sorts of circumstances.

Consequently, and contrary to common belief, "source-oriented lexis", in particular the lexis copied from general English, is not necessarily any easier to interpret. In England and Wales, three principal rules are generally used to help interpret legal documents: "the plain meaning rule or literal rule" (as its name indicates, the judges will stick to the literal meaning of the words), "the Golden rule or British rule" (it allows to depart from literal interpretation if the latter leads to an absurd result), and finally "the mischief rule" (it consists in endeavouring to find the spirit of the law if the letter of the law fails to produce acceptable results). It is not uninteresting to note that these rules are resorted to in order to clarify the meaning of words borrowed from plain English. For instance, the law holds that usurping a person's identity is a crime. In Whitely v. Chappel [1868] LR 4 QB 147 , it was held that as a "person" needs to be alive to exercise their right to vote, the defendant had not committed any crime when he usurped a dead person's identity for purposes of voting. Similarly, the Street Offences Act 1959 states that "[I]t shall be an offence for a common prostitute to loiter or solicit in a street or public place for the purpose of prostitution"21. In Smith v. Hughes (1960) 2 All E.R. 859, Lord Parker found against prostitutes who were calling passers-by from their balconies (and who were not, consequently, "in a street or a public place") ${ }^{22}$, arguing that everybody knew "this was an Act to clean up the streets"23. The courts will therefore strive to determine the meaning of plain English words by establishing the context in which they are used. In addition, in cases where lexemes are part of a list, judges may decide to apply the "ejusdem generis principle" ("of the same kind"). For instance, in Powell v. Kempton Park Racecourse (1899), the noun phrase "other place" was interpreted as meaning "other indoor place" as it was ending a list composed exclusively of such places ("house, office, room or other place").

However, such rules may prove of little use in cases where the lexemes are complex to understand per se. It is often the case with certain adverbs composed from the deictics "here" and "there" ("hereinafter", "thereof", etc.) which, as mentioned earlier, feature in legal dictionaries because they are used quite extensively in legal documents even though 
they do not carry any legal meaning whatsoever. The complexity of their interpretation lies in the fact that, firstly, they date back to thirteen centuries ago and are understandably considered archaic today; and secondly, they do not point to something that is always easy to identify in the context of the document (apart from common utterances such as "the parties hereto" or "the schedules hereof"). The archaism of certain lexemes is, in fact, often criticised as a barrier to understanding (much has been written on the use of the modal shall for that matter, mostly to suggest legal documents should be rid of it). The language of the law is known for keeping its loanwords over the centuries $^{24}$, and as such, antiquated lexemes are still very much part of legal English, including those that have no legal meaning but are nevertheless considered as "legal" because they are commonly used in legal documents and/or feature in legal dictionaries.

\section{Conclusion} consequence, if it is accepted that legal language resorts to all the means that contribute to expressing the communicative needs of the law, legal lexis is a characteristic of legal language in its broader definition in so far as it meets its communicative requirements. In 
this respect, an interesting line of enquiry would be to determine to what extent the characteristics of legal lexis (borrowings from other languages and domains, sourceoriented and recipient-oriented lexis, polysemy) are shared by other specialised languages in an attempt to conduct a comparative analysis of the use of specialised lexicons.

\section{BIBLIOGRAPHY}

CAMPBell BLACK Henry et al., 1988 [1983], Black's Law Dictionary, Saint Paul (Minn.): West Publishing Co.

Black's Law Dictionary, Free Online Legal Dictionary, second edition, http://thelawdictionary.org BEVERIDGE Barbara J., 2002, "Legal English - How it developed and why it is not appropriate for international legal contracts", in MATTILA Heikki (ed.), The Development of Legal Language, Helsinki: Talentum Media, 55-79, http://tradulex.com/articles/Beveridge.pdf BRANAA Jean-Éric et al., 2006, The English of Law: England and Wales, Paris: Belin. CORNU Gérard, 2005, 1990, Linguistique juridique, Paris : Montchrestien.

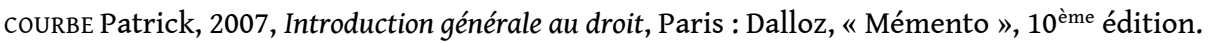
CRYSTAL David, 1995, 1991, The Cambridge Encyclopedia of the English Language, Cambridge: Cambridge University Press.

GARNER Bryan A., 1987, A Dictionary of Modern Legal Usage, New York, Oxford: Oxford University Press.

haspelmath, Martin, 2009, "Lexical borrowing: Concepts and issues" in HASPelmath Martin \& TADMOR Uri (eds.), Loanwords in the World's Languages: A Comparative Handbook, Berlin: De Gruyter Mouton, 35-54.

INNES Matthew, 2000, "Danelaw identities: Ethnicity, regionalism, and political allegiance”, in HADLEY DAWN M. \& RICHARDS Julian D. (eds.), Cultures in Contact: Scandinavian Settlement in England in the Ninth and Tenth Centuries, Turnhout: Brepols Publishers, 65-88.

ISANI Shaeda, 2011, "Developing professional cultural competence through the multi-layered cultural substrata of FASP: English for Legal Purposes and M. R. Hall's The Coroner", Les Cahiers de l'APLIUT, vol. XXXXI, 29-45, http://apliut.revues.org/1497 JOHNSON Samuel, 1755, A Dictionary of the English Language, London: W. Strahan. LADMIRAL Jean-René, 1986, « Sourciers et ciblistes », Revue d'esthétique, n10, 33-42. LERAT Pierre, 1995, Les langues spécialisées, Paris : PUF, collection « Linguistique nouvelle». LÉVY-ULLMANN Henri, 1999, Le système juridique de l'Angleterre, Paris : Éditions Panthéon Assas. LUPOI Maurizio, 2000, The Origins of the European Legal Order, Cambridge: Cambridge University Press. 
MATTILA Heikki, 2005, « Jurilinguistique et latin juridique », in GÉMAR Jean-Claude \& KASIRER Nicholas (eds.), Jurilinguistique/ics : entre langues et droits / Between Law and Language, Bruxelles : Bruylant et Montréal : Éditions Thémis, 71-89.

Nix v. Heddon 149 U.S 304 (1893), http://caselaw.findlaw.com/us-supreme-court/149/304.html

Oxford English Learners's Dictionary, 2015, Oxford University Press, http://

www.oxfordlearnersdictionaries.com

POLLOCK Frederick \& MAITLAND Frederic William, 1968 [1895], The History of English Law, vol.1, Cambridge: Cambridge University Press.

RESCHE Catherine, 2001, « Réflexions sur la frontière entre langue générale et langue spécialisée », in MÉMET Monique \& PETIT Michel (eds.), L'anglais de spécialité en France, Mélanges en l'honneur de Michel Perrin, Bordeaux : GERAS Éditeur Université Bordeaux 2, 37-46.

RICHARD Isabelle, 2006, « L'évolution de l'emploi de shall, de must, et du présent simple dans le discours juridique normatif, dans le cadre du Plain Language Movement ", ASp, 49-50, 137-153.

RICHARD Isabelle, 2008, L'anglais du droit - Interpréter les modaux en contexte normatif, Aix-enProvence : Presses Universitaires de Provence.

RICHARD Isabelle, 2014, “Metaphors in Law: Let Us Keep Them!”, La métaphore / Metaphors, Lexis Journal in English Lexicology, 8: http://journals.openedition.org/lexis/251 ROULAND Norbert, 1988, Introduction historique au droit, Paris : PUF, http://classiques.uqac.ca/ contemporains/rouland_norbert/intro_historique_droit/intro_historique_droit.html ROSCH Eleanor, 1983, "Prototype classification and logical classification: The two systems" in scholnick E. F. (ed.), New Trends in Conceptual Representation: Challenges to Piaget's Theory?, Hillsdale, NJ: Lawrence Erlbaum Associates, 73-86.

SOURIOUX Jean-Louis \& LERAT Pierre, 1975, Le langage du droit, Paris : PUF.

TAREV Boris V., 2012, "Lexical Borrowings: Linguistic and Didactics Aspects" in Journal of Siberian Federal University. Humanities \& Social Sciences 7, $\mathrm{n}^{\circ}$ 5, 944-950.

TOWNEND Matthew, 2002, Language and History in Viking Age England, Turnhout: Brepols Publishers. WEST Thomas, 2005, “The Council of Europe's French-English Legal Dictionary: an American lawyer analysis", in GÉMAR Jean-Claude \& KASIRER Nicholas (eds.), Jurilinguistique/tics : entre langues et droits / Between Law and Language, Brussels: Bruylant \& Montréal: Éditions Thémis, 431-443. WÜSTER Eugen, 1968, Dictionnaire multilingue de la machine-outil, London : Technical Press. young Warren, CAMERon Neil \& Tinsley Yvette, 1999, Juries in Criminal Trials, Part Two, Preliminary Paper 37(2), Wellington, Law Commission, http://www.nzlii.org/nz/other/nzlc/pp/PP37/ PP37.pdf

\section{NOTES}

1. The adjective "generic" is used in the sense that the law is general to a group (over a given territory) as opposed to applying to specifically identified individuals (Courbe [2007: 3-4]).

2. These documents, needed to start any legal action, were in use for about one thousand years in England and contributed to creating a centralised judiciary system and thus to enforcing a single system of law over the territory (Lupoi [2000: 303]). 
3. The tree metaphor is often used to describe the spreading of the different common law systems, the trunk representing the original English Common Law from which the other Common Law systems branched out (Richard [2014: 108-109]).

4. The generic term "Danes" referred to all the Scandinavian populations that settled in Northern and Eastern England towards the end of the $7^{\text {th }}$ century (Innes [2000: 78]). The term "Dane Law" (Dana Lagu) is used in the Anglo-Saxon Chronicle (annals written in old English recounting the history of the Anglo-Saxons) to refer to both the territory where these populations settled and the system of law they lived under.

5. This phenomenon, known as the "personality of law", comes from the Romans and expanded in Europe during the Middle Ages (Rouland [1988:336]). It concerns laws which regulate the condition of persons as opposed to those which regulate property and things.

6. Another reason that often accounts for foreign borrowings is prestige (Townend [2002: 203]). This is especially true of Latin (Beveridge [2002: 5]), as exemplified by Poland's new Supreme Court building in Warsaw which is decorated with maxims in Latin (Mattila [2005: 74]).

7. In reality, Common Law really developed during the reign of Henry II who is commonly considered as "the founder" of the Common Law as he established many of its founding principles.

8. Previous attempts were made, such as the Statute of Pleading passed by Parliament in 1362 imposing English in all courts of law so that the proceedings would be conducted in a language supposedly easier to understand for lay people.

9. These two categorisations are inspired by Ladmiral's [1986] binary theory of source language oriented and target language oriented translation strategies.

10. "Mortgage", from the French "gage mort", literally means that the debt is "dead".

11. In the same way, a "prayer" is defined as "a request addressed to the court" (Garner [1987: 426]). For instance, "age prayer" is a "suggestion of nonage, made by an infant party to a real action, with a prayer that the proceedings may be deferred until his full age. It is now abolished.". See http://thelawdictionary.org/age-prayer/

12. West [2005: 435-443] presents a large number of such differences between American and British legal languages.

13. Avoir tort means "to be wrong" in French while "a tort" is a civil wrong outside contract law. Though these meanings seem close on the face of it, the legal meaning is not transparent at all to a French-speaking person unfamiliar with the Common Law, especially since some negligence torts, one of the three types of tort, are viewed as no-fault liability torts (vicarious liability torts).

14. In such cases, the legal meaning is usually watered down (Resche [2001: 40]) or simplified in order to be operative in non-legal contexts and meet the requirements of non-legal communication. The lexemes are no longer "terms" but mere "words" and defined in a way that is accessible to lay people in general English dictionaries (sometimes with mistakes, from a legal point of view). Such lexis is sometimes called "sub-technical" or "semi-technical" by some authors (Baker, Cowan, Flowerdew, Trimble, etc.) if one adopts the lay users' point of view, but could also be called "flexible" due to their capacity to undergo semantic and conceptual simplification.

15. This definition assumes that the reader makes the difference between criminal law and civil law.

16. In this sense, para-legal lexis may be construed as borrowed from legal lexis for communication purposes.

17. http://thelawdictionary.org/fruit/

18. For instance, if a law concerns "birds", does it include ostriches though they cannot fly? (Crystal [1995: 374]).

19. http://thelawdictionary.org/vehicle/ 
20. The key notion "beyond reasonable doubt" in criminal law, which implies that jurors should not harbour the least doubt as to the defendant's guilt to convict them, often requires to be explained, as lay people often think that they may have some doubt, as long as it is "reasonable". In this respect, a study conducted in New Zealand in 1999 showed that the majority of those surveyed understood the phrase in terms of percentages which varied between $50 \%$ and $100 \%$ ! (Young, Cameron \& Tinsley [1999: 54]).

21. http://www.legislation.gov.uk/ukpga/Eliz2/7-8/57/section/1

22. http://home.loxfordlaw.co.uk/unit1/notes-on-statutory-interpretations

23. http://home.loxfordlaw.co.uk/unit1/notes-on-statutory-interpretations

24. As Bracton wrote in On the Laws and Customs of England (circ. 1235): "Lose a syllable, lose the cause", exemplifying how crucial it is to stick to the way things are worded in a legal system based on precedents: "[a] slight change in words meant that the action would fail (Beveridge [2002: 1], about the "prescribed form of writs").

\section{ABSTRACTS}

It is common knowledge that specialised languages use some aspects of "languages" to express the communicative objectives of specialised communities. Compiling and analysing specialised corpora is one way of identifying recurrent features that tend to shed light on these special uses. As a result, it is possible to draw a list of the linguistic characteristics specific to a given specialised language, such as the use of a special lexicon or special lexico-grammatical features. Some of these features are so specific compared to other varieties of languages, whether specialised or not, that they will naturally be identified as typical of, say, legal English, economic English and so on. Therefore, lexis - and, to some extent, grammar - appears to be distinct from one specialised language to another, or from non-specialised languages to specialised languages, which would tend to show that specialised lexicons, together with some grammatical features, are a defining feature of specialised languages. Yet, as we will show, much of legal lexis is shared by other types of language, in particular everyday, non-specialised language, which implies that legal lexis is necessarily polysemous. Therefore the question is: how legal/specialised is legal lexis? Or, put differently: what makes legal lexis legal? Can legal lexis be considered as a characteristic of legal language? This article will first focus on some of the borrowings that characterise legal lexis in English and then look at some of the interpretation difficulties posed by a number of lexical units that do not stand out as being "legal" but yet consistently appear in legal messages and feature, for some of them, in legal dictionaries.

Les langues spécialisées, comme on le sait, utilisent certains traits des langues naturelles afin de répondre aux besoins communicationnels des communautés spécialisées. Une façon d'identifier les caractéristiques récurrentes qui, a priori, reflètent ces utilisations particulières, consiste à compiler et analyser des corpus. Il est ainsi possible d'entreprendre de dresser une liste des caractéristiques linguistiques propres à une langue spécialisée donnée, comme l'utilisation d'un lexique particulier ou bien de traits lexico-grammaticaux spécifiques. Certaines de ces caractéristiques sont si singulières par rapport à d'autres variétés de langues, qu'elles soient spécialisées ou non, qu'on les identifiera comme étant typiques, par exemple, de l'anglais juridique, de l'anglais économique, etc. C'est pourquoi le lexique et, dans une certaine mesure, la grammaire, semblent distincts d'une langue spécialisée à l'autre, ou bien des langues non 
spécialisées aux langues spécialisées. On pourrait en conclure, dès lors, que lexique et grammaire font partie de ce qui définit le spécialisé d'une langue. Pourtant, comme nous le montrerons, la langue juridique partage une partie conséquente de son lexique avec d'autres langues, notamment la langue générale. Il en ressort que le lexique juridique est en grande partie polysémique. Dans quelle mesure, par conséquent, le lexique juridique est-il «juridique»? Autrement dit, quels sont les éléments qui permettent de le qualifier ainsi ? Peut-on considérer le lexique juridique comme une caractéristique de la langue juridique ? Nous nous proposons de décrire et d'expliquer certains des emprunts lexicaux propres à l'anglais juridique, puis de nous pencher sur les difficultés d'interprétation que posent certaines lexies qui ne semblent pas spécialement «juridiques » mais qui, pourtant, sont utilisées régulièrement dans les documents juridiques et figurent, pour certaines, dans les dictionnaires juridiques.

INDEX

Mots-clés: lexique juridique, langues spécialisées, polysémie, emprunts

Keywords: legal lexis, specialised languages, polysemy, loan words

\section{AUTHOR}

\section{ISABELLE RICHARD}

Université de Nantes

Isabelle.Richard@univ-nantes.fr 